American Journal of Environmental Sciences 5 (1): 94-98, 2009

ISSN 1553-345X

(C) 2009 Science Publications

\title{
Microbial Response to the Application of Amendments in a Contaminated Soil with Trace Elements
}

\author{
A. Branzini, M.S. Zubillaga and M.M. Zubillaga. \\ Soil Fertility and Fertilizers, Faculty of Agronomy, Buenos Aires University, \\ San Martin Avenue 4453, Buenos Aires, Argentine
}

\begin{abstract}
Problem Statement: The anthropogenic activities can cause adverse effects in soils, increasing in some situations trace elements contents, impacting negatively both the microbial biomass and activity. Among the practices used for the recovery of soil quality we can find the application of organic amendments or the product of their composting. These can adsorb trace elements decreasing their availability and increasing the soil microbial biomass. The microorganisms of the soil use to be considered as sensitive biological indicators of the changes produced in the soil quality. Approach: One processes to quantify soil biological activity is the respiration. The aim was to evaluate the effects of two organic amendments application on soil microbial activity, in a soil contaminated with copper $(\mathrm{Cu})$, zinc $(\mathrm{Zn})$ and chromium $(\mathrm{Cr})$. To prove the raised aim we quantified $\mathrm{CO}_{2}-\mathrm{C}$ release. Results: The results showed that at the end of the incubation period, as much in contaminated soils as in soils without contamination, the total activity of microorganisms was significantly increased by the application of organic amendments ( $\mathrm{p}=0.0062$ and $\mathrm{p}=0.0005$, respectively). The application of both composts to slightly acid soils increased the initial and final values of $\mathrm{pH}$. There was no evidence of modification in Electrical Conductivity (EC) because of compost application. At the end of the incubation period a negative relationship was observed between $\mathrm{EC}$ and $\mathrm{CO}_{2}-\mathrm{C}\left(\mathrm{R}^{2}=0.74, \mathrm{p}=\right.$ 0.0028). Conclusions: The obtained results in this study suggested that it was possible to increase the total activity of soil microorganisms and to reduce the bioavailability of $\mathrm{Cu}, \mathrm{Cr}$ and $\mathrm{Zn}$ in a contaminated soil. As a result, $\mathrm{CO}_{2}$-C release is a sensitive index of the soil quality, at least in the experimental conditions of this essay.
\end{abstract}

Key words: Cooper, zinc, chromium, compost, microbial activity

\section{INTRODUCTION}

Soil is a fundamental resource that provides important functions to the ecosystem ${ }^{[1]}$, as e.g., sheltering a wide richness of vegetable, animal and microbial species ${ }^{[2]}$.

During decades, soils have been submitted to the adverse effects of human activities, which negatively affect soil biological diversity; decreasing both the microbial biomass and activity ${ }^{[3,4]}$. Soil microorganisms are considered as sensitive biological indicators of the changes produced in soil quality ${ }^{[5,6]}$. One of the processes to quantify soil biological activity is the respiration $^{[7]}$. A decrease in respiration would indicate diminution in total microbial enzymatic activity and therefore in the mineralization of the organic matter ${ }^{[8]}$; thus being able to affect this way the normal functioning of the ecosystem ${ }^{[9]}$.
Soil microorganisms require a limited concentration of trace elements $(\mathrm{Cu}, \mathrm{Zn}, \mathrm{Cr}, \mathrm{Fe}, \mathrm{Mn}$ and $\mathrm{Mo}$ ), since they are cofactors in enzymatic processes and promote the correct cellular functioning. However a minimal increase in the concentration of these elements has a strong negative influence on processes mediated by microorganisms ${ }^{[10]}$.

One of the most important problems associated with trace elements contamination is that they cannot be degrade. In this way, for the soil quality reclamation it is possible the use of practices that stabilize these elements in soils. One of these practices is the application of organic amendments or the product of its composting $^{[11]}$, to produce changes in trace elements bioavailability ${ }^{[12]}$. These amendments contain significant amounts of humic substances (humans, fulvic and humic acids) that could adsorb trace elements temporarily ${ }^{[13,}{ }^{14]}$, trough quelates formation ${ }^{[15]}$, or by the formation of stables complexes

Corresponding Author: A. Branzini, Soil Fertility and Fertilizers, Faculty of Agronomy, Buenos Aires University, Saint Martin Avenue 4453, 54 (11) 4524-8073, Buenos Aires, Argentine 
Am. J. Environ. Sci., 5 (1): 94-98, 2009

sorb them for longer period of time. This allowed establish that incorporation of amendments to soil increase both microorganism's biomass and activity ${ }^{[16]}$. In addition, the above mentioned amendments are an excellent way of recycling both the nutrients and organic matter contained in biosolids; and the improvement in soil physical properties ${ }^{[17,18]}$.

The aim of this research was to evaluate the effect of two organic amendments (biosolid and equine compost) applied to a $\mathrm{Cu}, \mathrm{Cr}$ and $\mathrm{Zn}$ contaminated soil over its microbial activity. We expected that soil microorganism's activity will be restored with amendments application, as a result of the effect on trace elements bioavailability.

\section{MATERIALS AND METHODS}

Sampling methodology and samples contamination: The experience was developed with samples from the surface layer $(0-20 \mathrm{~cm})$ of the Ah horizon on a Typical Hapludoll (Sandy-loam texture: clay $19.2 \mathrm{~g} \mathrm{Kg}^{-1}$, silt $23.2 \mathrm{~g} \mathrm{Kg}^{-1}$, sand $\left.57.6 \mathrm{~g} \mathrm{Kg}^{-1}\right)$, proceeding from Buenos Aires province $\left(35^{\circ} 37^{\prime} \mathrm{S}, 61^{\circ} 22^{\prime} \mathrm{O}\right)$.

The samples were air-dried, homogenized and passed through a $2 \mathrm{~mm}$ sieve. The soil was enriched by solutions of $\mathrm{CuCl}_{2} 2 \mathrm{H}_{2} \mathrm{O}, \mathrm{H}_{2} \mathrm{CrO}_{4}$ and $\mathrm{ZnSO}_{4} 7 \mathrm{H}_{2} \mathrm{O}$, beyond the limits considered toxic by different standards ${ }^{[19,20]}$ : copper $(\mathrm{Cu}): 450 \mathrm{mg} \mathrm{kg}^{-1}$, chromium (Cr): $550 \mathrm{mg} \mathrm{kg}^{-1}$ and zinc ( $\left.\mathrm{Zn}\right): 630 \mathrm{mg} \mathrm{kg}^{-1}$. To achieve trace elements/colloidal fraction equilibrium, they have been submitted to five days cycles, of wetted up to field capacity and dried, during a period of 2 months, according to a modification of the methodology proposed by Martinez and Motto ${ }^{[21]}$. The organic amendments used were a biosolid and equine compost (Table 1) in equivalent doses to $100 \mathrm{Mg} \mathrm{ha}^{-1}$. These amendments were mixed with the contaminated and no contaminated soils and later were made 4 cycles of wetting and drying for their stabilization. The resulting treatments were: in soils without contamination: control soil (CS), CS + biosolid compost $(\mathrm{CS}+\mathrm{BC}), \mathrm{CS}+$ equine compost $(\mathrm{CS}+\mathrm{EC})$; and in contaminated soils: contaminated soil control (CSC), $\mathrm{CSC}+$ biosolid compost $(\mathrm{CSC}+\mathrm{BC})$ and $\mathrm{CSC}+$ equine compost $(\mathrm{CSC}+\mathrm{EC})$. All treatments were replicated three times in a complete randomized design.

Soil incubation test: The incubation test was proposed by ${ }^{[7]}$ with few minor modifications. In flasks of $360 \mathrm{~mL}$ were incorporated $100 \mathrm{~g}$ dry sample from each treatment. Each flask constituted an experimental unit. A container with $5 \mathrm{~mL}$ of $\mathrm{NaOH} 1 \mathrm{M}$ was placed into
Table 1: General characteristics of used compost. Limits of trace elements into different origin compost, from European Union

\begin{tabular}{lcc}
\hline Parameters & Biosolid compost & Equine compost \\
\hline $\mathrm{pH}(1: 2.5)$ & 7.50 & 8.75 \\
$\mathrm{EC}(1: 2.5) \mathrm{dSm}^{-1}$ & 1.29 & 0.86 \\
$\mathrm{C} / \mathrm{N}$ & 15.00 & 20.00 \\
$\mathrm{Cu}\left(\mathrm{mg} \mathrm{kg} \mathrm{DM}^{-1}\right)$ & 0.72 & 11.80 \\
$\mathrm{Cr}\left(\mathrm{mg} \mathrm{kg} \mathrm{DM}^{-1}\right)$ & 0.02 & $\mathrm{ND}$ \\
$\mathrm{Zn}\left(\mathrm{mg} \mathrm{kg} \mathrm{DM}^{-1}\right)$ & 0.66 & 62.50 \\
\hline Holland $=\mathrm{Cu}: 60 \mathrm{mg} \mathrm{kg}^{-1}$, & $\mathrm{Zn}: 200 \mathrm{mg} \mathrm{kg}^{-1} \mathrm{y}, \mathrm{Cr}: 50 \mathrm{mg} \mathrm{kg}^{-1}, \mathrm{DM}$ \\
$=$ Dry matter, ND = Not detectable
\end{tabular}

Table 2: Chemical characteristics of treatments at initial and final time of incubation test. Same letters indicated were not significant differences at the $95 \%$ level of probability, according to LSD test. (Soil $\mathrm{pH}$ and EC in extract was measured using 1: 2.5 soil: distillated water ratio)

\begin{tabular}{lllll}
\multicolumn{5}{c}{ measured using 1.2 .5 soil: distillated water ratio) } \\
& & & \\
& & & \\
Treatments & pH & $\mathrm{EC} \mathrm{dSm}^{-1}$ & $\mathrm{OC} \mathrm{g} \mathrm{kg}^{-1}$ & $\mathrm{TN} \mathrm{g} \mathrm{kg}^{-1}$ \\
\hline $\mathrm{CS}$ & $5.19 \mathrm{~cd}$ & $0.57 \mathrm{~d}$ & 14.5 & 2.25 \\
$\mathrm{CS}+\mathrm{BC}$ & $5.46 \mathrm{~b}$ & $0.62 \mathrm{~d}$ & 24.9 & 2.80 \\
$\mathrm{CS}+\mathrm{EC}$ & $5.89 \mathrm{a}$ & $0.86 \mathrm{~cd}$ & 15.7 & 4.01 \\
$\mathrm{CSC}$ & $5.09 \mathrm{~d}$ & $1.56 \mathrm{~b}$ & 18.3 & 2.21 \\
$\mathrm{CSC}+\mathrm{BC}$ & $5.36 \mathrm{bc}$ & $1.90 \mathrm{a}$ & 14.1 & 2.96 \\
$\mathrm{CSC}+\mathrm{EC}$ & $5.43 \mathrm{~b}$ & $1.18 \mathrm{c}$ & 16.0 & 2.47 \\
& & Final & & \\
$\mathrm{CS}$ & $5.00 \mathrm{~d}$ & $0.80 \mathrm{~d}$ & 2.04 & 0.281 \\
$\mathrm{CS}+\mathrm{BC}$ & $5.49 \mathrm{~b}$ & $0.50 \mathrm{e}$ & 1.11 & 0.243 \\
$\mathrm{CS}+\mathrm{EC}$ & $5.44 \mathrm{~b}$ & $1.08 \mathrm{c}$ & 2.42 & 0.256 \\
$\mathrm{CSC}$ & $5.17 \mathrm{c}$ & $1.53 \mathrm{ab}$ & 2.09 & 0.228 \\
$\mathrm{CSC}+\mathrm{BC}$ & $5.14 \mathrm{c}$ & $1.42 \mathrm{~b}$ & 2.09 & 0.313 \\
$\mathrm{CSC}+\mathrm{EC}$ & $5.71 \mathrm{a}$ & $1.70 \mathrm{a}$ & 0.92 & 0.293 \\
\hline
\end{tabular}

flask, which captured $\mathrm{CO}_{2}$ produced by the microbial activity. The incubation was kept at constant temperature of $28 \pm 2{ }^{\circ} \mathrm{C}$ and $60 \%$ of equivalent humidity. The flasks stayed closed, opening it daily half an hour to maintain the aerobic conditions. The $\mathrm{CO}_{2}-\mathrm{C}$ released was measured through titulation with $\mathrm{HCl} 0.25$ M, using phenolphthalein as indicator. The measurements were determinate on days $1,2,3,6,9$, 13,17 , then weekly and later, every two weeks until the stabilization of the microbial activity.

The soil chemical characteristics were determined at two moments of the incubation (initial and final), using standard methodologies ${ }^{[22]}$ (Table 2). The bioavailables concentrations of $\mathrm{Cu}, \mathrm{Cr}$ and $\mathrm{Zn}$ were extracted by $\mathrm{CaCl}_{2}$ and quantified by Atomic Absorption Spectrometry (AAS).

Results were statistically Analyzed by Analysis Of Variance (ANOVA) and differences among means were obtained by the Least Significant Differences (LSD) test. Trace elements were analyzed by factorial adjustment of $3 \times 2 \times 2$ (levels of compost, levels of contamination and moment of sampling); the means comparison was done with LSD test. The variances 
were stabilized when it was necessary using a logarithmic transformation of the data.

\section{RESULTS AND DISCUSSION}

Generally, the organic amendments addition increased significantly the initial and final $\mathrm{pH}$, in contaminated soils and in soils without contamination. Although these results were in good agreement with the obtained by other authors with the compost application $^{[23,24]}, \mathrm{pH}$ levels (between 5.19 and 5.89) were maintained within slightly acid soils (Table 2). Due to the little $\mathrm{pH}$ modification, it was not found correlation with trace elements bioavailability. In both soils mentioned above, amendments application did not modify significantly the EC (Table 2). However other authors have found increases in EC with the application of organic amendments ${ }^{[25]}$. On the other hand, when the incubation period was finished, it was observed that treatments with greater EC released minor amount of $\mathrm{CO}_{2}-\mathrm{C}\left(\mathrm{R}^{2}=0.74, \mathrm{p}=0.0028\right)$.

The $\mathrm{CO}_{2}-\mathrm{C}$ release pattern was generally similar in all treatments (Fig. 1). The final production of $\mathrm{CO}_{2}-\mathrm{C}$ accumulated in contaminated soils was lower than soils without contamination $(\mathrm{p}=0.0001)$. The application of both compost to no contaminated soil, increased the $\mathrm{CO}_{2}-\mathrm{C}$ released since the second day of the incubation $(\mathrm{p}=0.034)$. In general, it was observed that the biosolid compost application produced greater statistical significant released of $\mathrm{CO}_{2}-\mathrm{C}$, respect to equine compost. In contaminated soils, amendments application began to increase $\mathrm{CO}_{2}-\mathrm{C}$ production since the day 17 of incubation $(p=0.0125)$. We did not observed statistically significant differences among both composts. These results indicated that at the end of incubation period, as much in the contaminated and no contaminated soil, the organic amendments application significant increased the $\mathrm{CO}_{2}-\mathrm{C}$ production $(\mathrm{p}=0,0062$ and $\mathrm{p}=0,0005$, respectively) and consequently the total activity of the microorganisms (Fig. 1). It has been reported that in contaminated soils with trace elements, microorganism biomass and activity increased with organic amendments application ${ }^{[24]}$.

The used amendments showed lower levels of trace elements to the considered ones as toxics by different standards ${ }^{[19,20]}$. Their incorporation to soils did not modify initially their bioavailable levels neither in soils without contaminating nor contaminated. In fact, we did not find a significant relationship between each trace elements availability and $\mathrm{CO}_{2}-\mathrm{C}$ production. It is possible that these elements had addition effects.

In soils without contamination, $\mathrm{Cu}, \mathrm{Cr}$ and $\mathrm{Zn}$ concentrations did not differ significantly with time

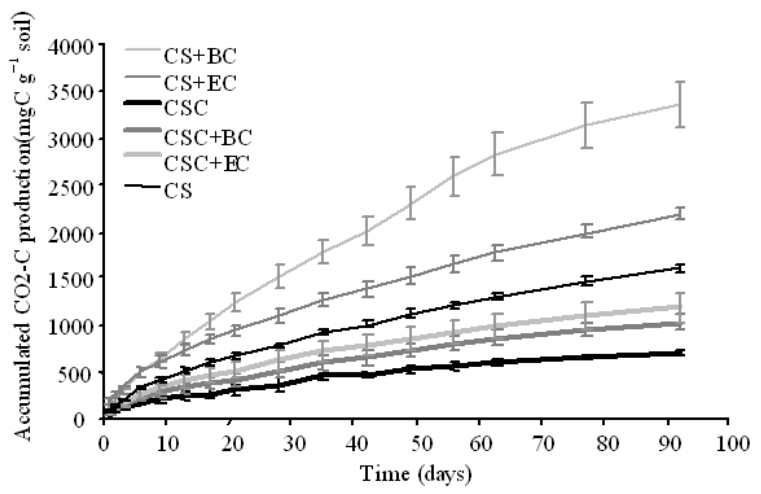

Fig. 1: Accumulated average $\mathrm{CO}_{2}-\mathrm{C}$ production (mg $\mathrm{C}$ $\mathrm{g}^{-1}$ soil) with incubation time. Vertical lines show the standard errors of the means
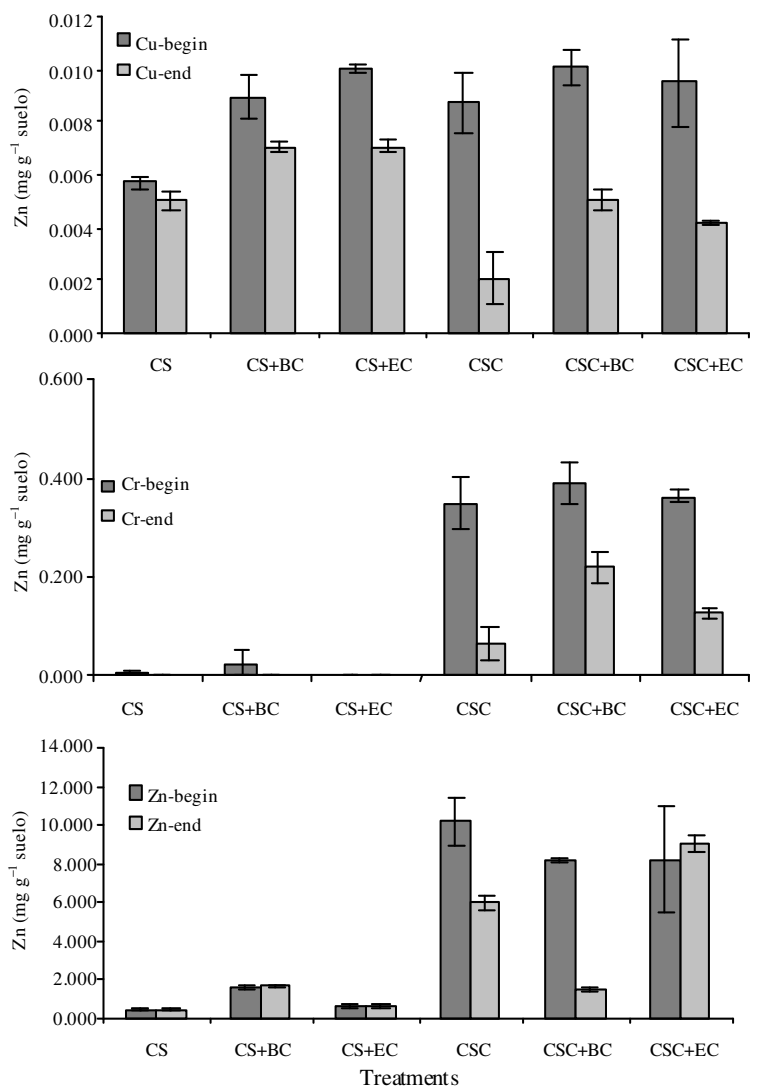

Fig. 2: Trace elements concentration in different treatments from the beginning (i) to the end (f) of the incubation test. Trace elements of treatments $\mathrm{CS}, \mathrm{CS}+\mathrm{BC}$ and $\mathrm{CS}+\mathrm{CE}$ were multiplicity for 10 . Vertical lines represent the standard errors of the means 
Am. J. Environ. Sci., 5 (1): 94-98, 2009

Table 3: Contamination effects, compost application and incubation time. Here are presented the $p$ values of the ANOVA and the contrast result

\begin{tabular}{llll}
\hline ANOVA $(p$ values $)$ & $\mathrm{Cu}$ & $\mathrm{Cr}$ & $\mathrm{Zn}$ \\
\hline Incubation time & 0.0000 & 0.0000 & 0.0023 \\
Contamination & 0.0000 & 0.0000 & 0.0000 \\
Compost & 0.0027 & 0.0398 & 0.0528 \\
Contamination x Incubation time & 0.0018 & 0.0000 & 0.0010 \\
Compost x Incubation time & 0.3114 & 0.2872 & 0.0028 \\
Compost x contamination & 0.6536 & 0.0444 & 0.0000 \\
Compost x contamination x & 0.1069 & 0.2634 & 0.0020 \\
Incubation time & & & \\
\hline Contrasts & & & \\
\hline Contamination vs. Incubation time & & & \\
CS & $\mathrm{NS}$ & $\mathrm{NS}$ & $\mathrm{NS}$ \\
CSC & $<0.0001$ & $<0.0001$ & 0.0001 \\
Compost vs. contamination & & & \\
CS & & $\mathrm{NS}$ & 0.0000 \\
CSC & & 0.0280 & 0.0001 \\
\hline
\end{tabular}

(Fig. 2). In general, the soil contaminated incubation diminished the trace elements bioavailability (Table 3 ). In the contaminated soil without amendment application this diminution could be produced by adsorption phenomena to the soil colloidal fraction, due to the greater electronegativity, or to the greater ionic strength of the trace elements ${ }^{[26]}$.

Tordoff et al. ${ }^{[27]}$ observed that mature compost with high proportion of humified organic matter and the increase of $\mathrm{pH}$ obtained with its incorporation to soils, diminished the bioavailability of trace elements in them $^{[28]}$. The humified organic matter proportion from used compost, varied between $86.7 \%$ for the biosolid compost and $88.5 \%$ for the equine one, which made possible the mentioned process. Generally, at the end of the incubation, the amendments application in contaminated soils significantly increased the trace elements bioavailability with respect to soil without amendment (Table 3, Fig. 2). This was observed by Van Herwijnen et al. ${ }^{[29]}$, attributing these results to the degradation in the time of organic matter contained into compost; reason why trace elements adsorbed in it was released to bioavailability forms. In our study we could realize the same reasoning due to the increase in microbial activity.

\section{CONCLUSION}

The total activity of microorganisms from contaminated soil increased by added amendments but it was always lower than no-contaminated soils. For this reason, we considered that the microorganism respiration is a sensible index of the soil quality. With incubation time, was observed diminution in the studied elements bioavailability. However with compost application it was not possible to demonstrate the same effect. We propose to continue with different long term studies, validating this methodology under field conditions; and complementing with microbial community studies.

\section{REFERENCES}

1. Larson, W.E. and F.J. Pierce, 1991. Conservation and enhancement of soil quality. Proceeding of the 12th Evaluation for Sustainable Land Management in Developing World, Sept. 15-21, International Board of Soil Research Management, Bangkok, Thailand, pp: 175-203.

2. Nogales, B., 2005. La Microbiología del Suelo en la Era de la Biología Molecular: Descubriendo la Punta del Iceberg. Ecology: Scientific and Technological. J. Ecol. Environ., 14: 41-51. http://www.revistaecosistemas.net/pdfs/116.pdf.

3. Chander, K. and P.C. Brookes, 1991. Microbial biomass dynamics during the decomposition of glucose and maize in metal contaminated soils. Soil Bio. Biochem., 23: 917-925. http://cat.inist.fr/?aModele $=$ afficheN\&cpsidt $=5125$ 876.

4. Giller, K.E., E. Witter and S.P. McGrath, 1998. Toxicity of heavy metals to micro-organisms and microbial processes in agricultural soils: A review. Soil Bio. Biochem., 30: 1389-1414. DOI: 10.1016/S0038-0717(97)00270-8.

5. Carter, M.R., 1986. Microbial biomass as an index for tillage induced changes in soil biological properties. Soil Tillage Res., 7: 29-40.

6. Torstensson, L., 1996. Microbial Assays in Soil. In: Soil Ecotoxicology, Bitton Tarradellas J.G. and D. Rossel, (Eds.). CRC Press Inc., Boca Raton, Florida, pp: 386. ISBN: 1566701341, 9781566701341

7. Alvarez, R., R. Díaz, N. Barbero, O.J. Santanatoglia and L. Blotta, 1995. Soil organic carbon, microbial biomass and $\mathrm{CO} 2-\mathrm{C}$ production from three tillage systems. Soil Tillage Res., 33: $17-28$.

http://www.ingentaconnect.com/content/els/01671 987/1995/00000033/00000001/art00432;jsessionid =h0uon4b0vpnd.alice?format=print.

8. Valsecchi, G., C. Gicliotti and A. Farini, 1995. Microbial biomass, activity and organic accumulation in soils contaminated with heavy metals. Biol. Fert. Soils, 20: 253-259.

DOI: 10.1007/BF00336086.

9. Hinajosa, B.M., J.A. Carreira, R. García-Ruíz and P.R. Dick, 2004. Soil moisture pre-treatment effects on enzyme activities as indicators of heavy metal-contaminated and reclaimed soils, Soil Bio. Biochem., 36: 1559-1568. DOI: 10.1016/j.soilbio.2004.07.003. 
10. Lee, I.S., O.K. Kim, Y.Y. Chang, B. Bae, H.H. Kim and K.H. Baek, 2002. Heavy metal concentrations and enzyme activities in soil from a contaminated Korean shooting range. J. Biosci. Bio. Eng., 94: 406-411. DOI: 10.1016/S13891723(02)80217-1.

11. Paré, T., E.G. Gregorich and H. Dinel, 1997. Effects of stockpiled and composted manures on germination and initial growth of cress (Lepidium sativum). Bio. Agric. Hortic., 14: 1-11. http://library.wur.nl/WebQuery/artik/lang/899608.

12. Walker, D.J., R. Clemente, A. Roig and M.P. Bernal, 2003. The effects of soil amendments on heavy metal bioavailability in two contaminated mediterranean soils. Environ. Pollut., 122: 303-312. DOI: 10.1016/S02697491(02)00287-7.

13. Castaldi, P. and P. Melis, 2004. Grown and yield characteristics and heavy metals content on tomatoes in different growing media. Commun. Soil Sci. Plant Anal., 35: 85-98.

DOI: $10.1081 / C S S-120027636$

14. Basta, N.T., J.A. Ryan and R.L. Chaney, 2005. Trace elements chemistry in residual-treated soil: Key concepts and metal bioavailability. J. Environ. Qual., 34: 49-63.

http://www.cababstractsplus.org/abstracts/Abstract. aspx?AcNo=20053029010.

15. Adriano, D.C., 2001. Trace Elements in the Terrestrial Environments: Biogeochemistry, Bioavailability and Risks of Heavy Metals. 2nd Edn. Springer, New York, pp: 867. ISBN-10: 0387986782.

16. Perucci, P., 1992. Enzyme activity and microbial biomass in a field soil amended with municipal refuse. Bio. Fert. Soils, 14: 54-60.

DOI: 10.1007/BF00336303.

17. Sanchez-Monedero, M.A., C. Mondini, M. De Nobili, L. Leita and A. Roig, 2004. Land application of biosolids. Soil response to different stabilization degree of the treated organic matter. Waste Manage., 24: 325-332. DOI: 10.1016/j.wasman.2003.08.006.

18. Pascual, J.A., T. Hernández, C. García and A. García, 1998. Changes in the organic matter mineralization rates of an arid soil after amendment with organic wastes. Arid Soil Res. Rehabilitat., 12: 63-72.

http://md1.csa.com/partners/viewrecord.php?reque ster $=$ gs \&collection $=$ ENV \& recid $=4480331 \& q=$ Cha nges+in+the+organic+matter+mineralization+rates +of+an+arid+soil+after+amendment+with+organic + wastes.\&uid $=\&$ setcookie $=$ yes

19. European Union CEC-Council of the European Communities, 1986. Council directive on the protection of the environment and in particular of the soil, when sewage sludge is used in agriculture http://europa.eu/scadplus/leg/en/lvb/128088.htm.
20. USEPA-U.S. Environmental Protection Agency, 1993. Standards for the Use or Disposal of Sewage Sludge. http://www.aeibrookings.org/publications/abstract.php?pid=489.

21. Martínez, C.E. and H.L. Motto, 2000. Solubility of lead, zinc and cooper added to mineral soils. Environ. Pollu., 107: 153-158. DOI: S02697491(99)00111-6.

22. Faithfull, N.T., 2004. Methods in Agricultural Chemicals Analysis: A Practical Handbook.1st Edn. CAB International Publishing Wallingford, Oxon, pp: 292. ISBN: 978-84-200-1044-1.

23. Castaldi, P., L. Santona and P. Melis, 2005. Heavy metal immobilization by chemical amendments in a polluted soil and influence on white lupine growth. Chemosphere, 60: 365-371. DOI: 10.1016/j.chemosphere.2004.11.098.

24. Pérez de Mora, A., P. Burgos, E. Madejón, F. Cabrera, P. Jaeckel and M. Schloter, 2006. Microbial community structure and function in a soil contaminated by heavy metals: Effects of plant growth and different amendments. Soil Bio. Biochem., 38: 327-341.

DOI: 10.1016/j.soilbio.2005.05.010.

25. Sastre-Conde, I., J.G. Cabezas, A. Guerrero, M.A. Vicente and M.C. Lobo, 2007. Evaluation of the soil biological activity in a remediation soil assay using organic amendments and vegetal cover. Sci. Total Environ., 378: 205-208. DOI: 10.1016/j.scitotenv.2007.01.038.

26. Tordoff, G.M., A.J.M. Baker and A.J. Willis, 2000. Current approaches to the revegetation and reclamation of metalliferous mine wastes. Chemosphere, 41: 219-228. DOI: 10.1016/S00456535(99)00414-2.

27. Flogeac, K., E. Guillon and M. Aplincourt, 2007. Competitive sorption of metal ions onto a northeastern France soil. Isotherms and XAFS studies. Geoderma, 139: 180-189.

DOI: 10.1016/j.geoderma.2007.01.016.

28. Shuman, L.M., 1999. Organic waste amendments effect on zinc fractions of two soils. J. Environ. Qual., 28: 1442-1447.

http://jeq.scijournals.org/cgi/content/abstract/28/5/ 1442.

29. Van Herwijnen, R., T.R. Hutchings, A. Al-Tabbaa, A.J. Moffat, M. Johns and S.K. Ouki, 2007. Remediation of metal contaminated soil with mineral amended compost. Environ. Pollu., 150: 347-354. DOI: 10.1016/j.envpol.2007.01.023. 